\title{
Genetic characterization and evaluation of anthropogenic impacts on genetic patterns in cultured and wild populations of mussels (Mytilus galloprovincialis) from Greece
}

\author{
I.A. Giantsis ${ }^{1}$, N. Kravva ${ }^{2}$ and A.P. Apostolidis ${ }^{1}$
}

${ }^{1}$ Laboratory of Ichthyology and Fisheries, Department of Animal Production, Faculty of Agriculture, Aristotle University of Thessaloniki, Thessaloniki, Greece ${ }^{2}$ Department of Fisheries, Region of Central Macedonia, Regional Section of Halkidiki, Polygyros, Greece

Corresponding author: A.P. Apostolidis

E-mail: apaposto@agro.auth.gr

Genet. Mol. Res. 11 (4): 3814-3823 (2012)

Received March 14, 2012

Accepted May 24, 2012

Published August 17, 2012

DOI http://dx.doi.org/10.4238/2012.August.17.14

\begin{abstract}
Despite the great commercial and economic importance of mussels, Mytilus galloprovincialis (Bivalvia, Mollusca) in Greece, little information is available concerning their population genetic structure. We used RAPD markers to examine genetic differentiation and potential impact of aquaculture practices and other anthropogenic activities on the genetic structure of two cultivated and eight wild mussel populations collected from one Turkish and nine Greek coast sites. Five random decamer primers were chosen, among 34 tested, for the analysis of 433 individuals. Eighty-eight bands (genetic loci) were scored, all of which were polymorphic. No indication of reduced genetic variability was observed in the cultured populations. In contrast, a loss in genetic diversity was observed in populations from two localities (Canakkale and Kalochori) that are heavily polluted by chemical contaminants. $F_{\mathrm{ST}}$
\end{abstract}


analyses and exact tests revealed significant heterogeneity among $M$. galloprovincialis population samples, although their genetic divergence seemed to be independent of geographic distances. Anthropogenic activities, i.e., marine pollution and transplantation of mussels, appear to have played an important role in shaping patterns of genetic diversity and differentiation among Greek M. galloprovincialis populations.

Key words: Mytilus galloprovincialis; Genetic diversity; Pollution; Population structure; RAPD; Anthropogenic impact

\section{INTRODUCTION}

The Mediterranean mussel (Mytilus galloprovincialis Lamarck, 1819) is the indigenous species of mussel of the Eastern Mediterranean coasts. Its biological traits, such as fast growth, immunity to parasites and disease, stress tolerance, and high survivorship (Branch and Steffani, 2004), in combination with its preferred environmental conditions prevailing in Greece, have greatly contributed to the large development of Greek mussel populations over the past decades (Smaal, 2002), which have become a very important resource for the national economy. The annual mussel production in Greece is approximately 40,000 tons, of which more than $80 \%$ comes from the Thermaikos Gulf (Mouratidou et al., 2006). The Thermaikos Gulf is a semi-closed bay in the Northwestern Aegean Sea, which is plentiful in organic material due to a delta formed by the deposition of the 4 rivers within it. Hence, it exhibits excellent conditions for mussel farming, particularly at the area of Chalastra that is located at the outflow of 3 rivers. At the neighboring coasts of Turkey, although there are currently only 2 mussel farms in Marmara and the Aegean Sea producing 1100 tons/year, there is a high potential for further spread of these mussel populations (Karayücel et al., 2010).

In important fisheries and aquaculture resources such as marine bivalves, knowledge of population structure is critical and can aid in refining existing management models (Graves, 1998). It is widely accepted that population genetics is an essential and efficient tool for the management and conservation of wild and adaptive populations (Gray, 1996). Several types of genetic markers have been frequently applied in population genetic studies of aquatic organisms. In mussels of the genus Mytilus, previous studies dealt with species and hybrid identification (Beaumont et al., 2008) and with their population structure in Western Europe (Daguin and Borsa, 1999) and America (Addison et al., 2008). However, despite its utility for aquaculture purposes, few reports have been published regarding the population genetic structure of M. galloprovincialis along the Greek and Turkish coastlines. Thus, the only available information comes from 2 studies of mitochondrial DNA (mtDNA) and allozyme polymorphisms performed on a few populations from the North Aegean Sea (Karakousis and Skibinski, 1992; Kravva et al., 2000, respectively). Nevertheless, the utility of allozyme markers in aquaculture genetics has become limited recently (Liu and Cordes, 2004), as the unusual manner of mtDNA inheritance in mussels obscures inferences about the population structure of the species. Therefore, a study conducted at the genomic DNA level to monitor the genetic diversity of $M$. galloprovincialis populations from the East Mediterranean Sea is still missing.

The random amplified polymorphic DNA (RAPD) technique has been demonstrated to be a helpful methodology for estimating genetic variations at the molecular level in marine 
bivalves (Joaquim et al., 2010). RAPD is a low cost, rapid method that can be performed without any prior nucleotide sequence knowledge of the target DNA. The latter advantage has made the RAPD technique a very useful tool for studying the genetics of non-model species, in which little genome information is available (Klinbunga et al., 2010). Its simplicity and rapidity is mainly due to the use of a single, short and arbitrary oligonucleotide primer for amplification of the template DNA, thus avoiding the need for expensive and sophisticated equipment (Bardakci, 2001). It should also be noted that RAPD usually reveals great polymorphism levels and it can be applied to entire genomes.

The present study was focused on the investigation of the genetic differentiation of natural and cultured M. galloprovincialis populations from the Aegean and Ionian coasts. Furthermore, we attempted to examine the possible anthropogenic impact (aquaculture practices, water pollution, or other aspects) on the genetic structure of mussel populations. We believe that the results of this study will contribute to the rational management of resident mussel populations, especially in a long-term survival situation.

\section{MATERIAL AND METHODS}

\section{Sampling}

A total of $450 \mathrm{M}$. galloprovincialis individuals were collected by hand, outside of the water (due to the phenomenon of the tide) or by diving, from 9 localities in Greek waters (8 from the North, East, and West Aegean Sea and 1 from the Ionian Sea) and 1 in Turkey (near Canakkale, in the middle of Dardanelles, a narrow strait that connects the Aegean Sea with the Sea of Marmara) (Figure 1). Two of the collected samples (Chalastra and Epanomi) came from cultured populations, while all the rest were wild. Sampling took place between January and April 2009. After collection, the mussels were kept alive until their transportation to the laboratory for the DNA extraction.

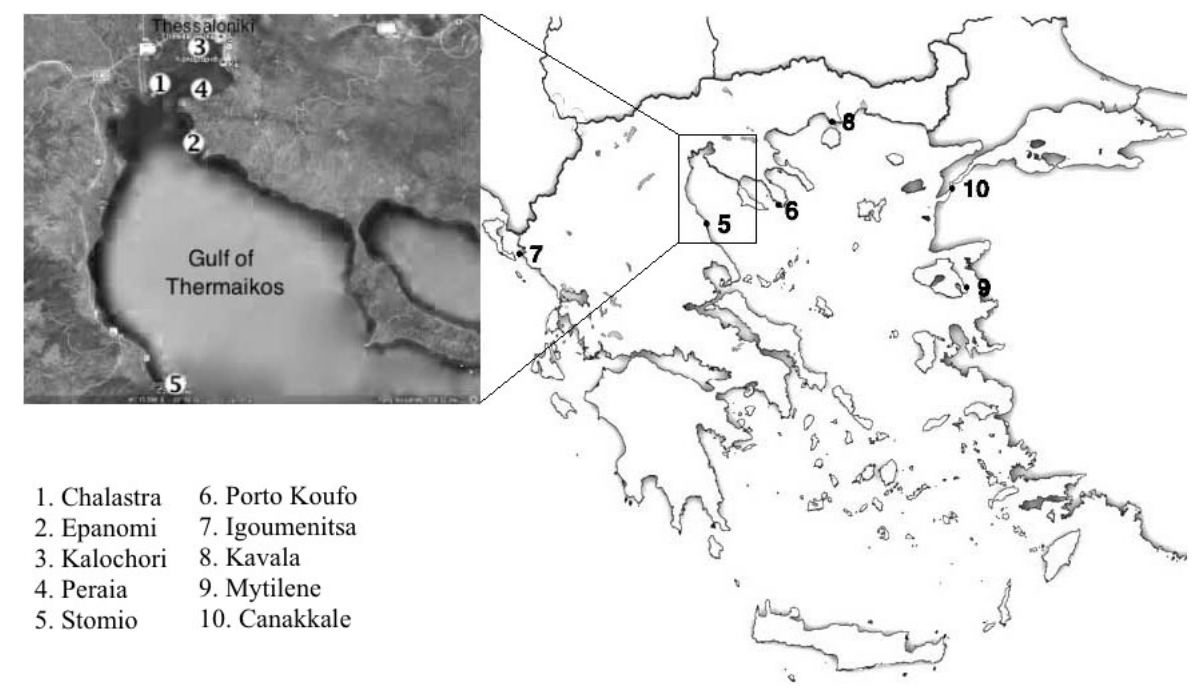

Figure 1. Map showing sampling locations of the 10 Mytilus galloprovincialis populations analyzed in this study. 


\section{Isolation of genomic DNA and RAPD-PCR amplification}

Total DNA was isolated according to the protocol of Hillis et al. (1996). Thirtyfour decamer primers, all purchased from Operon Technologies (Alameda, CA, USA), were screened on 3 to 5 individuals of each population. Five primers (Table 1), exhibiting easy scoring results and high polymorphism and reproducibility, were chosen for further genetic analysis of the populations. RAPD-PCRs were performed in a $15-\mu \mathrm{L}$ reaction volume containing 50 ng genomic DNA, 1 U Taq DNA polymerase (HyTest Ltd., Finland), $1.5 \mu \mathrm{L} 10 \mathrm{X}$ Taq DNA polymerase buffer $\left(670 \mathrm{mM}\right.$ Tris- $\left.\mathrm{HCl}, \mathrm{pH} 8.8,166 \mathrm{mM}\left(\mathrm{NH}_{4}\right)_{2} \mathrm{SO}_{4}\right), 3 \mathrm{mM} \mathrm{MgCl}$, $0.25 \mathrm{mM}$ of each dNTP, and $20 \mathrm{pmoL}$ primer. Amplification reactions were carried out in an Eppendorf Thermocycler programmed for the following reaction: initial denaturation for 4 min at $94^{\circ} \mathrm{C}, 35$ cycles of denaturation $\left(40 \mathrm{~s}\right.$ at $\left.94^{\circ} \mathrm{C}\right)$, annealing $\left(1 \mathrm{~min}\right.$ at $\left.38^{\circ} \mathrm{C}\right)$, and extension $\left(75 \mathrm{~s}\right.$ at $\left.72^{\circ} \mathrm{C}\right)$, followed by a final extension at $72^{\circ} \mathrm{C}$ for $7 \mathrm{~min}$. One negative control without template DNA was also included to avoid any possible contamination. RAPD-PCR products were separated by gel electrophoresis with $1.5 \%$ agarose $(\mathrm{w} / \mathrm{v})$ in $1 \mathrm{X}$ TBE $(0.89 \mathrm{M}$ Tris, $0.89 \mathrm{M}$ boric acid, $0.11 \mathrm{M} \mathrm{Na}$ EDTA, $\mathrm{pH}$ 8.3) buffer containing ethidium bromide, compared with a GeneRuler ${ }^{\text {TM }}$ 100-bp DNA ladder (Fermentas Life Sciences, Canada), visualized, and photographed under an ultraviolet Vilber Lourmat, France trans-illuminator. To overcome limitations of the technique mainly related to reproducibility due to its sensitivity to changes in reaction conditions (Bardakci, 2001), 2 RAPD-PCR replications were performed for every sample and every primer. Bands that were reproduced after the 2 replications were considered reliable. Moreover, RAPD patterns were analyzed by 2 independent researchers.

\section{Data analysis}

RAPD-PCR products are dominant markers, thus heterozygotes are indistinguishable from homozygotes. Allelic information was therefore based on the assumption that genotype frequencies are in Hardy-Weinberg equilibrium and alleles in homozygous recessive individuals, as well as in dominant ones, are in identical states (Zhou et al., 2000). Hence, a binary matrix was made in which every band was scored as " 1 " for its presence or as a " 0 " for its absence. This matrix was used for statistical analysis to calculate the effective allele number $\left(N_{\mathrm{E}}\right)$, Shannon index $(I)$, mean heterozygosity $(H)$ at species and population level, and the values of genetic distance $(D)$ (Nei, 1978) between the populations using the POPGENE version 1.31 software (Yeh et al., 1999). Based on these values, an unweighted pair group method with arithmetic mean (UPGMA) dendrogram was constructed with 1000 bootstrap replicates.

Population genetic differentiation was examined using exact tests in all possible pairwise comparisons. Moreover, $F_{\mathrm{ST}}$ values were estimated using the RAPDFST program (Black, 1995) on various groups of populations, i.e., 1) all samples, 2) all Aegean samples, and 3) all Thermaikos Gulf samples. The gene flow among populations was estimated as the number of individuals per generation that migrate from a population to another. Many authors have suggested that estimation of gene flow according to $F_{\mathrm{ST}}$ values is more preferable than using methods of allele frequency data (Zhou et al., 2000). Here, it was calculated by the $F_{\mathrm{ST}}$ value (RAPDFST software; Black, 1995) using the equation $N_{\mathrm{m}}=\left(1-F_{\mathrm{ST}}\right) / 4 F_{\mathrm{ST}}$. Finally, the Mantel test was carried out (Mantel, 1967) to examine the correlation between genetic and coastal geographic distances using GENALEX version 6.41 (Peakall and Smouse, 2006). 


\section{RESULTS}

\section{RAPD polymorphism}

The 5 selected primers were successfully amplified in 433 M. galloprovincialis individuals from 10 populations, generating a total of 88 clear, stable, and reproducible fragments (genetic loci), with a size range from 150 to $1900 \mathrm{bp}$. The number of scored bands per primer in all populations ranged from 15 to 21 (Table 1). All amplified fragments were polymorphic at species level; however, all primers failed to yield a diagnostic band, i.e., present in all individuals of 1 population and at the same time absent from the others, which could lead to the identification of the various geographic populations.

\begin{tabular}{|c|c|c|}
\hline Primer code & Sequence (5'-3') & Number of bands scored \\
\hline OPF 03 & CCTGATCACC & 21 \\
\hline OPA 04 & AATCGGGCTG & 17 \\
\hline OPA 15 & TTCCGAACCC & 19 \\
\hline OPA 16 & AGCCAGCGAA & 15 \\
\hline OPA 18 & AGGTGACCGT & 16 \\
\hline
\end{tabular}

The values of the basic genetic parameters for each population are presented in Table 2. The average $N_{\mathrm{E}}$ was 1.312 at the population and 1.350 at species level. $I$ was 0.309 and 0.3623 at population and species level respectively, while (assuming Hardy-Weinberg equilibrium) the average $H$ was estimated to be 0.1969 within populations and 0.2231 at the species level (Table 2).

Table 2. Basic genetic variability parameters at the ten populations detected by random amplified polymorphic DNAs.

\begin{tabular}{|c|c|c|c|c|c|}
\hline Population & $N$ & $\mathrm{P}(\%)$ & $N_{\mathrm{E}}$ & $I$ & $H$ \\
\hline Chalastra & 44 & 80.68 & 1.3187 & 0.3230 & 0.2042 \\
\hline Epanomi & 42 & 75 & 1.3055 & 0.3063 & 0.1961 \\
\hline Kalochori & 44 & 78.41 & 1.3010 & 0.2984 & 0.1764 \\
\hline Peraia & 44 & 79.55 & 1.3196 & 0.3195 & 0.2016 \\
\hline Stomio & 44 & 72.73 & 1.3135 & 0.3059 & 0.1975 \\
\hline Porto Koufo & 43 & 79.55 & 1.3032 & 0.3095 & 0.1961 \\
\hline Igoumenitsa & 43 & 76.14 & 1.3108 & 0.3018 & 0.1934 \\
\hline Kavala & 42 & 71.59 & 1.3508 & 0.3199 & 0.2142 \\
\hline Mytilene & 43 & 81.82 & 1.3297 & 0.3262 & 0.2106 \\
\hline Canakkale & 44 & 72.73 & 1.2680 & 0.2801 & 0.1785 \\
\hline Species level & & 76.81 & 1.3500 & 0.3623 & 0.2231 \\
\hline
\end{tabular}

$N=$ sample size; P $(\%)=$ percentage of polymorphic loci; $N_{\mathrm{E}}=$ effective number of alleles per locus; $I=$ Shannon's diversity index; $H=$ heterozygosity.

\section{Genetic distances and genetic differentiation}

Values of Nei's (1978) pairwise genetic distance among the different geographic populations ranged from 0.0056 (between the 2 cultured samples of Chalastra and Epanomi) to 0.0731 (between Canakkale and Stomio), with an average $D=0.0386$ (Table 3). The UPGMA 
tree shown in Figure 2 illustrates the genetic relationships among the 10 populations studied. The bootstrap values were highly significant (100\%) only for the branch of the 2 cultured populations, while all of the remaining values were less than $75 \%$. The Mantel test did not reveal any correlation between geographic and genetic distances either at the macrogeographical scale when all samples were included $(\mathrm{r}=0.06, \mathrm{P}=0.30)$, or within the restricted area of the Thermaikos Gulf $(\mathrm{r}=-0.02, \mathrm{P}=0.45)$. Pairwise exact tests revealed that with the exception of the 2 cultured populations (Chalastra and Epanomi), all remaining population pairs showed significant levels of genetic heterogeneity. This was further supported by the results of $F_{\mathrm{ST}}$ analyses; the genetic differentiation among the 10 studied populations was $F_{\mathrm{ST}}=0.105$ $(\mathrm{P}<0.001)$ and translated to 2.1 migrants per generation $\left(N_{\mathrm{m}}\right)$. Genetic population subdivision was less evident, but still significant $(\mathrm{P}<0.001)$, among the Aegean populations (omitting the samples of Igoumenitsa and Canakkale) and among the 4 populations of the Thermaikos Gulf $\left(F_{\mathrm{ST}}=0.099\right.$ and 0.062 , respectively).

\begin{tabular}{|c|c|c|c|c|c|c|c|c|c|c|}
\hline Population & Chalastra & Epanomi & Kalochori & Peraia & Stomio & Porto Koufo & Igoumenitsa & Kavala & Mytilene & Canakkale \\
\hline Chalastra & $* * *$ & & & & & & & & & \\
\hline Epanomi & 0.0056 & $* * *$ & & & & & & & & \\
\hline Kalochori & 0.0207 & 0.0160 & $* * *$ & & & & & & & \\
\hline Peraia & 0.0149 & 0.0170 & 0.0191 & $* * *$ & & & & & & \\
\hline Stomio & 0.0312 & 0.0348 & 0.0413 & 0.0391 & $* * *$ & & & & & \\
\hline Porto Koufo & 0.0253 & 0.0249 & 0.0293 & 0.0272 & 0.0422 & $* * *$ & & & & \\
\hline Igoumenitsa & 0.0340 & 0.0336 & 0.0233 & 0.0339 & 0.0610 & 0.0408 & $* * *$ & & & \\
\hline Kavala & 0.0508 & 0.0588 & 0.0673 & 0.0490 & 0.0558 & 0.0543 & 0.0413 & $* * *$ & & \\
\hline Mytilene & 0.0323 & 0.0368 & 0.0369 & 0.0309 & 0.0660 & 0.0447 & 0.0558 & 0.0278 & $* * *$ & \\
\hline Canakkale & 0.0480 & 0.0450 & 0.0367 & 0.0451 & 0.0731 & 0.0201 & 0.0367 & 0.0635 & 0.0352 & $* * *$ \\
\hline
\end{tabular}

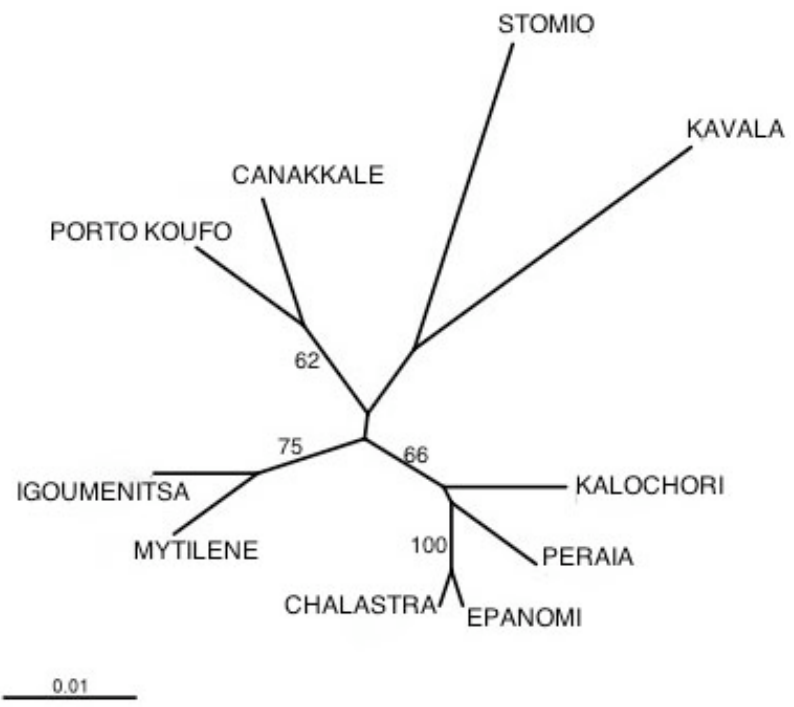

Figure 2. UPGMA tree illustrating the genetic relationships among all Mytilus galloprovincialis populations analyzed based on Nei's genetic distance. Branch lengths reflect genetic distance according to scale. 


\section{DISCUSSION}

RAPD markers have been successfully applied in a range of phylogenetic, taxonomic, and genetic diversity studies (Bardakci, 2001; Hammad and Qari, 2010). In the present study, the RAPD technique was very useful, thus providing important information about the genetic pattern of $M$. galloprovincialis populations. The limitation of yielding a diagnostic marker band to discriminate one population from another was not unforeseen. Such diagnostic bands are usually obtained by the RAPD technique in freshwater species (Jug et al., 2004; Apostolidis et al., 2011), but are rarely seen in marine species, due to the absence of barriers to migration and gene flow (Mamuris et al., 1998).

\section{Genetic diversity}

Since all of the RAPD-generated bands were found to be polymorphic at species level, the frequency of polymorphism was $100 \%$. However, it was not the same among the 10 populations that were studied, varying between 71.59 and $81.82 \%$ for the populations from Kavala and Mytilene, respectively (Table 2). Nevertheless, the proportion of polymorphic loci is not regarded as a good method to describe genetic variation, while more appropriate measures like effective number of alleles and heterozygosity are more efficient estimators (Elmaci et al., 2007; Tiira and Primmer, 2009). Especially for RAPD data, $I$ is considerably suitable since it remains unaffected by the method's inability to distinguish heterozygous individuals but also does not require the presumption that populations are in Hardy-Weinberg equilibrium (Dawson et al., 1995).

As shown in Table 2, all 3 diversity measures mentioned above did not reveal any loss in genetic variability of the 2 cultured populations (Chalastra and Epanomi). Reduced genetic variability caused by inbreeding is a frequently occurring phenomenon with several possible deleterious effects in cultured fish and shellfish populations originating from hatchery stocks (Kong and Li, 2007). Nevertheless, 2 systems of mussel culture are applied in Greece, bouchot mussel culture and the long-line system, neither of which includes artificial fertilization of eggs (Gosling, 2003). Instead, spat is collected from traps (ropes or wooden stakes) involving large numbers of mating individuals, which are not closely related. It seems that the applied aquaculture practices in Greek mussel farms (at least according to the results from the two studied samples) have not affected their genetic variability.

In contrast, intensely reduced values of genetic diversity appeared in the wild populations of Canakkale and Kalochori (Table 2). Apart from stochastic sampling errors, a possible explanation of this phenomenon could be the heavy environmental pollution in these areas. Indeed, the levels of water pollution in the marine area of Canakkale exceed the limit values according to the World Health Organization (WHO) and the Environmental Protection Agency (EPA), mainly due to the deposition of approximately 280 tons cadmium and 4500 tons lead reaching the Dardanelles from the Danube River (Yilmaz and Sadikoglu, 2011). Similarly, approximately 120,000-150,000 tons of municipal wastewater are deposited daily in the marine area of Kalochori via a pipe (Karvelas et al., 2003). Violintzis et al. (2009) revealed that total organic carbon, acid volatile sulfur, and some toxic elements $(\mathrm{Pb}, \mathrm{Zn}, \mathrm{Cu}, \mathrm{As})$ are in very high concentrations in this area, thus presenting a significant risk to the local biota.

Although earlier approaches of environmental pollution influence on aquatic organisms were focused on mechanisms of damage on test organisms exposed in laboratory 
settings to calculate biomass shifts and mortality proportion, recent studies emphasize the genetic impact as determined by a wide variety of DNA techniques (Belfiore and Anderson, 2001). RAPD markers, in particular, have proven to be not only useful to infer genotoxicrelated population genetic effects, but also capable to preliminarily evaluate the different routes in which toxic exposure may influence the genetic patterns of natural populations (De Wolf et al., 2004). Toxicants may increase the genetic diversity of a population by affecting the mutation rate, or decrease it through selection of more tolerant genotypes, bottleneck effects, or alteration of migration rates (Maes et al., 2005). In any case, the consequences of such change could be catastrophic for the long-term survival of the population and also for the entire biotope.

\section{Population genetic structure}

Exact tests and $F_{\mathrm{ST}}$ values showed significant genetic structuring among populations, whereas, as revealed by the UPGMA tree (Figure 2) and the Mantel test, the genetic divergence among populations was independent of the geographic distances among collecting sites. Such results are common in Mytilus species and have been reported in a number of studies, including those for populations of $M$. chilensis along Chilean coasts using RAPD markers (Toro et al., 2004) and for M. californianus from Californian coasts using allozyme, mtDNA, and single-copy nuclear DNA markers (Addison et al., 2008).

The total average effective number of $N_{\mathrm{m}}$ was calculated to be 2.1 for all populations sampled and 2.3 for the 8 Aegean populations. These values of $N_{\mathrm{m}}$ are higher than 1 migrant per generation needed to prevent differentiation by random genetic drift, while at the same time small enough to allow significant genetic structuring. Low levels of gene flow were evident even at the restricted area of the Thermaikos Gulf (Table 4), reinforcing further the restricted dispersal ability around Greek coasts. Setting aside limitations of the RAPD technique (dominant inheritance and questionable reproducibility), biological parameters coupled with oceanographic conditions prevailing in the studied area and random transport via shipping are some of the reasons that might explain the observed genetic structuring. The Aegean Sea is characterized by a complex hydrography and is influenced by a low-salinity outflow from Dardanelles. The latter forms large and strong sea streams (Olson et al., 2007), which might either contribute to great mobility of gametes and adult mussels or act as barriers to this movement. On a microgeographical scale, the cyclonic flow of the Thermaikos Gulf (Kravva et al., 2000) may be partly responsible for the weak congruence between genetic and geographic distances among local populations (Figure 2).

However, particularly for the Greek mussel populations, repeated transplantations may

Table 4. Pairwise genetic differentiation $\left(F_{\mathrm{ST}}\right)$ and number of migrants $\left(N_{\mathrm{m}}\right)$ per generation among Mytilus galloprovincialis samples of Thermaikos Gulf.

\begin{tabular}{lcc}
\hline Geographic level & $F_{\text {ST }}$ & $N_{\mathrm{m}}$ \\
\hline Epanomi - Chalastra & 0.018 & 13.5 \\
Epanomi - Kalochori & 0.031 & 7.8 \\
Epanomi - Peraia & 0.035 & 6.9 \\
Peraia - Kalochori & 0.036 & 6.7 \\
Peraia - Chalastra & 0.032 & 7.5 \\
Kalochori - Chalastra & 0.037 & 6.6 \\
\hline
\end{tabular}


have also played an important role in the absence of geographic structure. Indeed, numerous mussel farms have been developed along Greek coasts in the past decades and there are unrecorded reports that at least their initial spat originated from distant locations, mainly from Chalastra. In such a case, Chalastra, which was the first place in Greece where mussel culture took place, could be characterized as the natural source of mussel spat. Our results reinforce these reports, as this seems to be the case for the 2 cultured populations that we studied (Chalastra and Epanomi), which were found to be genetically homogenized, presenting double levels of gene flow in comparison with the rest populations of the Gulf (Table 4) and also sharing the smallest genetic distance $(D=0.0056)$ and the highest bootstrap values among all populations (Figure 2). However, before conclusions are drawn, further research using more DNA markers (such as microsatellites) and more populations from a broader geographical range is needed to investigate population genetic structure and differentiation between sampling localities of the species.

This report describes the first comprehensive genetic research study of Greek mussel populations, which was based on nuclear DNA markers. Our results suggest that anthropogenic activities may affect the genetic pattern of an organism in many different ways. Even though aquaculture practices did not seem to influence the genetic diversity of cultured mussels, marine pollution and human-mediated transport of mussels have possibly affected natural populations, with unresolved economic or environmental consequences.

\section{ACKNOWLEDGMENTS}

Research supported by the Prefecture of Thessaloniki, Greece. The authors also wish to thank Güroy Betül Kut and Mylonas G. Ioannis for their valuable assistance in sample collection.

\section{REFERENCES}

Addison JA, Ort BS, Mesa KA and Pogson GH (2008). Range-wide genetic homogeneity in the California sea mussel (Mytilus californianus): a comparison of allozymes, nuclear DNA markers, and mitochondrial DNA sequences. Mol. Ecol. 17: 4222-4232.

Apostolidis AP, Gelia D and Mamuris Z (2011). Genetic diversify among Balkan Trout populations based on RAPD Analysis. Russ. J. Genet. 47: 973-978.

Bardakci F (2001). Random amplified polymorphic DNA (RAPD) markers. Turk. J. Biol. 25: 185-196.

Beaumont AR, Hawkins MP, Doig FL, Davies IM, et al. (2008). Three species of Mytilus and their hybrids identified in a Scottish Loch: natives, relicts and invaders? J. Exp. Mar. Biol. Ecol. 367: 100-110.

Belfiore NM and Anderson SL (2001). Effects of contaminants on genetic patterns in aquatic organisms: a review. Mutat. Res. 489: 97-122.

Black WCIV (1995). FORTRAN Programs for the Analysis of RAPD-PCR Markers in Populations. Colorado State University, Fort Collins.

Branch GM and Steffani NC (2004). Can we predict the effects of alien species? A case-history of the invasion of South Africa by Mytilus galloprovincialis (Lamarck). J. Exp. Mar. Biol. Ecol. 300: 189-215.

Daguin C and Borsa P (1999). Genetic characterisation of Mytilus galloprovincialis Lmk. in North west Africa using nuclear DNA markers. J. Exp. Mar. Biol. Ecol. 235: 55-65.

Dawson IK, Simons AJ, Waugh R and Powell W (1995). Diversity and genetic differentiation among subpopulations of Gliricidia sepium revealed by PCR-based assays. Heredity 74 (Pt 1): 10-18.

De Wolf H, Blust R and Backeljau T (2004). The use of RAPD in ecotoxicology. Mutat. Res. 566: 249-262.

Elmaci C, Oner Y, Ozis S and Tuncel E (2007). RAPD analysis of DNA polymorphism in Turkish sheep breeds. Biochem. Genet. 45: 691-696.

Gosling E (2003). Bivalve Molluscs. Biology, Ecology and Culture. Fishing News Books, Oxford.

Graves JE (1998). Molecular insights into the population structures of cosmopolitan marine fishes. J. Hered. 89: 427-437.

Gray AJ (1996). The Genetic Basis of Conservation Biology. In: Conservation Biology (Spellerberg IF, ed.). Longman, 
Edinburgh, 115-121.

Hammad I and Qari SH (2010). Genetic diversity among Zygophyllum (Zygophyllaceae) populations based on RAPD analysis. Genet. Mol. Res. 9: 2412-2420.

Hillis DM, Moritz C and Mable BK (1996). Molecular Systematics, 2nd edn. Sinauer Associates Inc., Sanderland.

Joaquim S, Pereira J, Leitão A, Matias D, et al. (2010). Genetic diversity of two Portuguese populations of the pullet carpet shell Venerupis senegalensis, based on RAPD markers: contribution to a sustainable restocking program. Helgol. Mar. Res. 64: 289-295.

Jug T, Dove P, Pohar J and Snoj A (2004). RAPD analysis as a tool for discriminating marble trout from hybrids (marble trout $\mathrm{x}$ brown trout) in the zones of hybridization. J. Anim. Breed. Genet. 121: 156-162.

Karakousis Y and Skibinski DOF (1992). An analysis of allozyme, mitochondrial DNA and morphological variation in mussel (Mytilus galloprovincialis) populations from Greece. Experientia 48: 878-881.

Karayücel S, Çelik MY, Karayücel I and Erik G (2010). Growth and Production of Raft Cultivated Mediterranean Mussel (Mytilus galloprovincialis Lamarck, 1819) in Sinop, Black Sea. Turk. J. Fish. Aquat. Sci. 10: 9-17.

Karvelas M, Katsoyiannis A and Samara C (2003). Occurrence and fate of heavy metals in the wastewater treatment process. Chemosphere 53: 1201-1210.

Klinbunga S, Yuvanatemiya V, Wongphayak S, Khetpu K, et al. (2010). Genetic population differentiation of the blue swimming crab Portunus pelagicus (Portunidae) in Thai waters revealed by RAPD analysis. Genet. Mol. Res. 9: 1615-1624.

Kong L and Li Q (2007). Genetic comparison of cultured and wild populations of the clam Coelomactra antiquata (Spengler) in China using AFLP markers. Aquaculture 271: 152-161.

Kravva N, Staikou A and Triantaphyllidis C (2000). Genetic composition and temporal genetic variation in Mytilus galloprovincialis populations of the Thermaikos gulf (Northern Aegean Sea). Biologia 55: 289-297.

Liu ZJ and Cordes JF (2004). DNA marker technologies and their applications in aquaculture genetics. Aquaculture 238: 1-37.

Maes GE, Raeymaekers JA, Pampoulie C, Seynaeve A, et al. (2005). The catadromous European eel Anguilla anguilla (L.) as a model for freshwater evolutionary ecotoxicology: relationship between heavy metal bioaccumulation, condition and genetic variability. Aquat. Toxicol. 73: 99-114.

Mamuris Z, Apostolidis AP, Theodorou AJ and Triantaphyllidis C (1998). Application of random amplified polymorphic DNA (RAPD) markers to evaluate intraspecific genetic variation in red mullet (Mullus barbatus). Mar. Biol. 132: 171-178.

Mantel N (1967). The detection of disease clustering and a generalized regression approach. Cancer Res. 27: 209-220.

Mouratidou T, Kaniou-Grigoriadou I, Samara C and Kouimtzis T (2006). Detection of the marine toxin okadaic acid in mussels during a diarrhetic shellfish poisoning (DSP) episode in Thermaikos Gulf, Greece, using biological, chemical and immunological methods. Sci. Total Environ. 366: 894-904.

Nei M (1978). Estimation of average heterozygosity and genetic distance from a small number of individuals. Genetics 89: 583-590.

Olson DB, Kourafalou VH, Johns WE, Samuels G, et al. (2007). Aegean surface circulation from a satellite-tracked drifter array. J. Phys. Oceanogr. 37: 1898-1917.

Peakall R and Smouse PE (2006). GENALEX 6: genetic analysis in Excel. Population genetic software for teaching and research. Mol. Ecol. Notes 6: 288-295.

Smaal AC (2002). European mussel cultivation along the Atlantic coast: production status, problems and perspectives. Hydrobiologia 484: 89-98.

Tiira K and Primmer CR (2009). Genetic Diversity and Fitness-Related Traits in Endangered Salmonids. In: Population Genetics for Animal Conservation (Bertorelle G, Bruford MW, Hauffe HC, Rizzoli A, et al., eds.). Cambridge University Press, Cambridge, 241-268.

Toro JE, Ojeda JA and Vergara AM (2004). The genetic structure of Mytilus chilensis (Hupé 1854) populations along the Chilean coast based on RAPDs analysis. Aquac. Res. 35: 1466-1471.

Violintzis C, Arditsoglou A and Voutsa D (2009). Elemental composition of suspended particulate matter and sediments in the coastal environment of Thermaikos Bay, Greece: delineating the impact of inland waters and wastewaters. $J$. Hazard. Mater. 166: 1250-1260.

Yeh FC, Yang R and Boyle T (1999). POPGENE Version 1.31. A Microsoft Window-Based Freeware for Population Genetic Analysis. University of Alberta, Canada.

Yilmaz S and Sadikoglu M (2011). Study of heavy metal pollution in seawater of Kepez harbor of Canakkale (Turkey). Environ. Monit. Assess. 173: 899-904.

Zhou X, Faktor O, Applebaum SW and Coll M (2000). Population structure of the pestiferous moth Helicoverpa armigera in the eastern Mediterranean using RAPD analysis. Heredity 85 (Pt 3): 251-256. 